\title{
Complete trisomy 9 in two liveborn infants
}

\author{
STEPHANOS MANTAGOS, JOHN W MCREYNOLDS, \\ MARGRETTA R SEASHORE, AND W ROY BREG
}

From the Department of Human Genetics and Pediatrics, Yale University School of Medicine, New Haven, Connecticut, USA

SUMMARY Two unrelated newborn infants with multiple malformations were found to have complete trisomy 9 in all cells examined. In both, the phenotype was similar, consisting of characteristic facial appearance (microphthalmia, bulbous nose, micrognathia, cleft palate, low set ears), skeletal abnormalities (dislocated joints, flexion contractures of the fingers), cardiovascular malformations (persistent left superior vena cava, ventricular septal defect), hypoplastic genitalia, renal anomalies, and central nervous system malformations. Both died during the first few hours of life. Comparison of these two infants with the previously reported cases reveals a consistent pattern of malformations and very short survival associated with trisomy 9.

These cases illustrate the importance of doing chromosome studies on infants with congenital malformations dying in the newborn period and the usefulness of such studies in counselling parents regarding the risk of recurrence.

Trisomy of chromosome 9 in its entirety appears to be a rare abnormality in liveborn infants. Complete trisomy 9 is used to indicate trisomy for the entire chromosome without evidence of mosaicism. Trisomy 9 mosaicism refers to the presence of both trisomy 9 and normal cells. Although a number of abortuses with trisomy 9 have been reported, ${ }^{12}$ only three liveborn infants with this chromosome abnormality have been described. ${ }^{3-6}$ We now report Received for publication 25 November 1980 two unrelated newborn infants with multiple congenital malformations in whom trisomy for chromosome 9 was found. The similarity of clinical features in these infants is indicative of a distinct phenotype associated with trisomy 9 .

\section{Case reports}

CASE 1

This term male infant (fig 1), born to a 17-year-old primigravida, was delivered by caesarian section

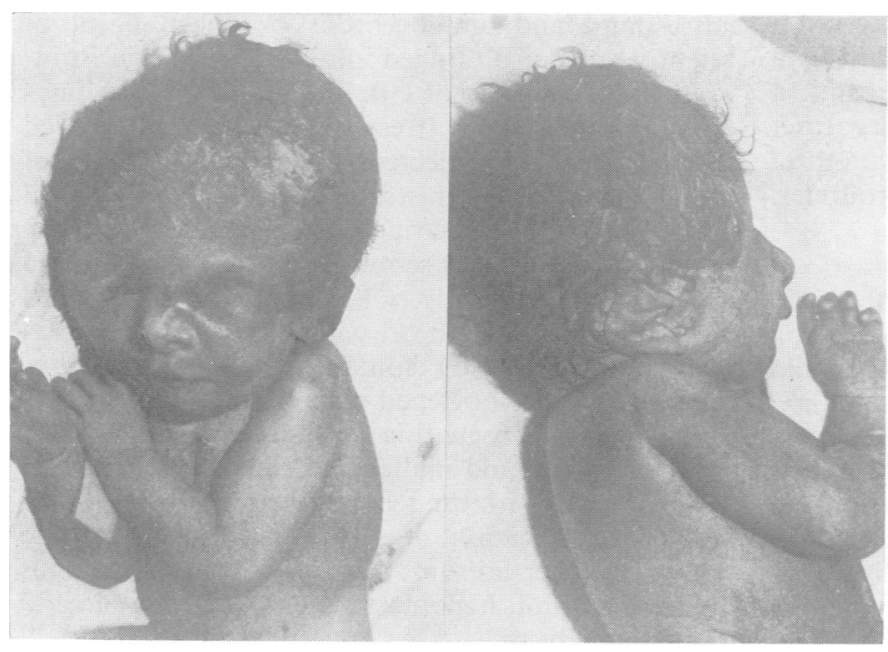

FIG 1 Frontal and lateral views of head and face of case 1 . 
because of failure of progression of labour after 17 hours of pitocin stimulation. The pregnancy had been uncomplicated. No exposure to radiation or known mutagens was reported and the family history was unremarkable. The father was 18 years old and healthy. There was no consanguinity. Since the birth of the patient the mother has delivered a phenotypically normal male whose karyotype studied prenatally showed no abnormality.

Apgar scores were 1 and 2 at 1 and 5 minutes, respectively. The birthweight was $1700 \mathrm{~g}$ (below the 3 rd centile), head circumference $31 \mathrm{~cm}$ (below the $3 \mathrm{rd}$ centile), and length $47 \mathrm{~cm}$ (10th centile). A prominent cephalohaematoma was present in the left parietotemporal area.

The face was small with bulbous nose, short palpebral fissures, microphthalmia, micrognathia, cleft palate, and low set malformed ears. The fingers and toes demonstrated camptodactyly and hypoplastic nails. Bilateral dislocated hips, flexion contractures of the knees, rocker-bottom feet, equinovalgus deformity, and broad malformed big toes were present. The phallus was small and no testes could be palpated in the hypoplastic scrotum. Neurological evaluation revealed hypertonia and absent primitive reflexes. He died 8 hours after birth.

Radiographic findings not clinically apparent included bilateral dislocations of the elbows and of the metatarsophalangeal joints of the big toes, coronal synostosis, and hypoplasia of the pelvis and of the proximal tibial epiphyses.

Necropsy revealed several malformations of the brain, heart, and urinary tract not previously detected. In the brain there was partial agenesis of the corpus callosum and several dysplastic areas, including the Sylvian fissure, hypothalamus, medial septal region, and basis pontis. The heart showed a small muscular ventricular septal defect (VSD), a widely patent ductus arteriosus (PDA), and a persistent left superior vena cava. Urinary tract abnormalities included a small posterior urethral valve and bilateral hydronephrosis with hydroureter.

\section{CASE 2}

This $1070 \mathrm{~g}$ (below the 3 rd centile) female infant (fig2) was the product of a 35-week gestation born to a 23-year-old primigravida mother and a 22-year-old father. There was no known parental consanguinity. The pregnancy was complicated by severe intrauterine growth retardation first noted at 20 weeks' gestation. There was no history of exposure to radiation or known mutagens during pregnancy, neither was there a family history of genetic disorders. Ultrasound examination at 30 weeks revealed a decreased amount of amniotic fluid and a biparietal
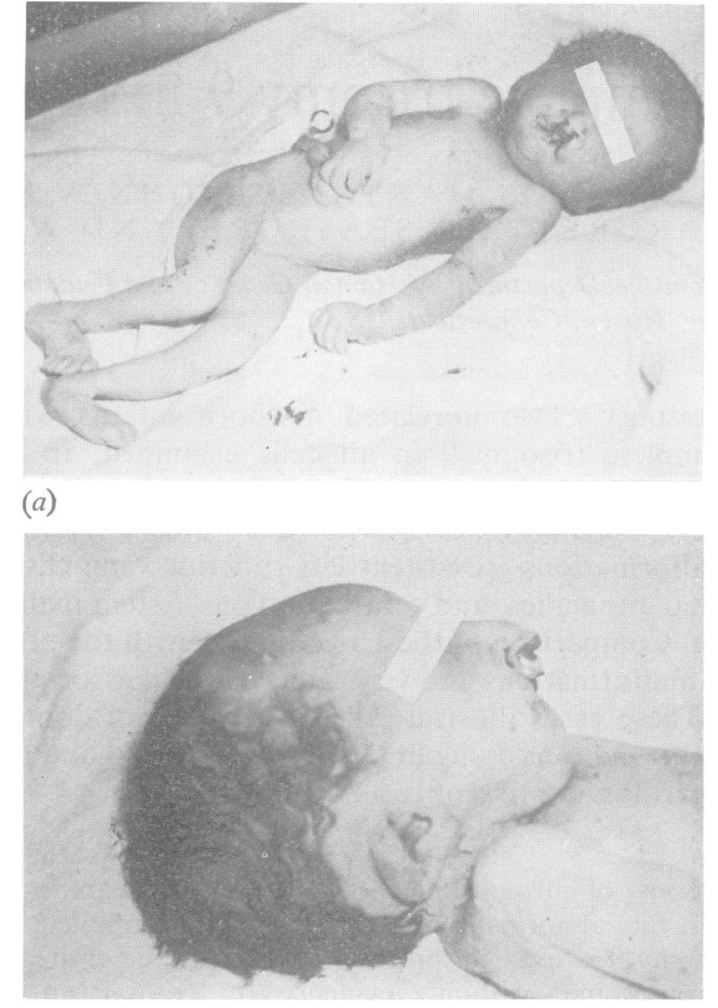

(b)

FIG 2 (a) Full view of case 2. (b) Lateral view of head and face of case 2.

diameter more consistent with 27 to 28 weeks' gestation.

At 34 weeks no amniotic fluid was detected by ultrasound and amniocentesis produced $6 \mathrm{ml}$ of slightly greenish tinged fluid with a lecithin/ sphingomyelin ratio of $1 \cdot 0$. Because of these findings fetal abnormality or stress or both was anticipated and early delivery elected. Following two days of dexamethasone administration for induction of fetal lung maturation, caesarian section was performed.

The infant's Apgar scores were 2 and 2 at 1 and 5 minutes, respectively. Multiple malformations included a globular head with widely open sutures and large posterior fontanelle, bilateral microphthalmia with shortened palpebral fissures, left iris coloboma, micrognathia, bilateral cleft lip and palate, low set and malformed ears, camptodactyly of the fingers with the second overlapping the third, bilateral dislocation of the hips, hyperextensible knees, rocker-bottom feet with equinovalgus deformity, and hypoplastic genitalia. She died 2 hours after birth. 


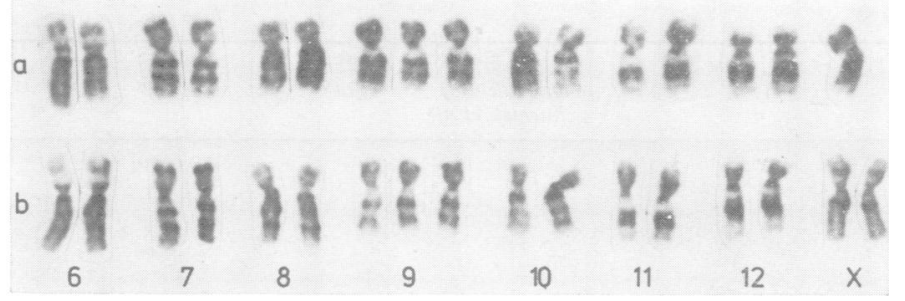

FIG 3 Representative partial karyotypes showing three chromosomes 9 in the $C$ group (6-12+X) from case 1 (a, upper row) and case 2 ( $b$, lower row).
The necropsy revealed a large membranous ventricular septal defect, failure of fissure formation in both lungs, and incomplete descent of the thymus. Duplication of the renal artery and urinary collecting system was found bilaterally. Both kidneys had numerous subcapsular cysts with immature glomeruli and dilated Bowman's capsules. The brain weight was $70 \mathrm{~g}$ and showed no gross developmental malformation.

\section{CYTOGENETIC STUDIES}

Chromosomes from peripheral lymphocytes from both cases and their parents and from fibroblasts cultured from skin biopsies of each patient were studied using a standard Giemsa banding technique with the following results.

Case 1. Each of 15 cells from the lymphocyte culture and 20 skin fibroblasts showed trisomy $9(47, \mathrm{XY},+9)$ without any other karyotype abnormality (fig 3a). No chromosome abnormality was found in the parents' cells. None of the chromosomes 9 from the patient and his parents had a distinctive heteromorphism of the variable region of the long arm (9qh), so it was not possible to determine whether the extra No 9 was of maternal or paternal origin.

Case 2. All 12 lymphocytes and 100 skin fibroblasts demonstrated trisomy $9(47, X X,+9)$ but no other chromosomal abnormality was found in these cells (fig 3b). The karyotypes of both parents were normal. No distinctive markers were present on any of the chromosomes 9 of these subjects (proband and parents) making it impossible to determine the origin of the extra chromosome.

\section{Discussion}

In 1973, Feingold and Atkins reported the first documented example of trisomy 9 in a male infant with multiple malformations who survived for 28 days. ${ }^{34}$ The prominent clinical features in that case were small palpebral fissures, bulbous nose, low set ears, hypoplastic genitalia, and malformations of the heart, brain, and skeleton. Seabright et $a l^{5}$ subsequently reported another infant with a similar phenotype and trisomy 9 who lived for 16 hours, while the case reported by Mace et al ${ }^{6}$ died after about $3 \frac{1}{2}$ months. We have described two further cases of complete trisomy 9 in liveborn infants and note a striking phenotypic similarity to the previously reported cases.

The clinical features of this syndrome are presented in table 1 and include the following: abnormal facies with small palpebral fissures, microphthalmia, bulbous nose, micrognathia, cleft palate, low set ears, cardiovascular anomalies (VSD, persistent left superior vena cava), skeletal abnormalities, camptodactyly, genitourinary anomalies (hypoplastic genitalia, intra-abdominal testes, duplication of the renal artery and urinary collecting system, kidney cysts, glomerular abnormalities, hydronephrosis, and a posterior urethral valve), and maldevelopment of the brain. Skeletal abnormalities seem to be one of the most characteristic features and one or more have been present in all cases reported, although of different severity in each one. These abnormalities include absence or hypoplasia of bones of the extremities (most commonly of fingers and toes) and dislocation and flexion deformities of joints (table 2). Bilateral dislocation of the hips has been present in all infants reported except the one described by Feingold and Atkins $^{3}$ and Kurnick et al, ${ }^{4}$ who did however have bilaterial dislocation of the head of the radius.

In general the clinical spectrum of abnormalities in trisomy 9 (partial or complete) varies with the amount of chromosomal material for which the subject is trisomic. Partial trisomy for the short arm of chromosome 9, for example, is characterised mainly by facial abnormalities (microcephaly, bulbous nose, microphthalmia, abnormal ears) and abnormalities of the fingers (hypoplastic phalanges and nails). ${ }^{7}$ In partial trisomy of the long arm of this chromosome additional abnormalities involving the joints, genitalia, and heart become apparent. ${ }^{89}$ The clinical features of trisomy 9 mosaicism are very similar to those of the complete trisomy, ${ }^{10-12}$ the main difference being that infants with mosaicism usually live longer than those with complete trisomy 9 , who are usually aborted or live only a few hours or days. 
TABLE 1 Clinical findings in cases with trisomy 9

\begin{tabular}{|c|c|c|c|c|c|}
\hline & Case 1 & Case 2 & $\begin{array}{l}\text { Feingold } \\
\text { and Atkins }{ }^{3} \text {; } \\
\text { Kurnick et al } \text { al }^{4}\end{array}$ & $\begin{array}{l}\text { Seabright } \\
\text { et als }\end{array}$ & $\begin{array}{l}\text { Mace } \\
\text { et al } 6\end{array}$ \\
\hline Intrauterine growth retardation & + & + & - & + & + \\
\hline $\begin{array}{l}\text { Craniofacial } \\
\text { Small palpebral fissures and/or microphthalmia } \\
\text { Bulbous nose } \\
\text { Micrognathia } \\
\text { Cleft palate } \\
\text { Low set ears }\end{array}$ & $\begin{array}{l}+ \\
+ \\
+ \\
+ \\
+\end{array}$ & $\begin{array}{l}+ \\
+ \\
+ \\
+ \\
+\end{array}$ & $\begin{array}{l}+ \\
+ \\
+ \\
+ \\
+\end{array}$ & $\begin{array}{l}* \\
* \\
+ \\
+ \\
+\end{array}$ & $\begin{array}{l}+ \\
+ \\
+ \\
+ \\
+\end{array}$ \\
\hline Skeletal & + & + & + & + & + \\
\hline $\begin{array}{l}\text { Cardiovascular } \\
\text { Persistent left superior vena cava } \\
\text { Septal defects } \\
\text { Persistent ductus arteriosus }\end{array}$ & $\begin{array}{l}+ \\
+ \\
+\end{array}$ & $\frac{-}{+}$ & $\begin{array}{l}+ \\
+ \\
+\end{array}$ & $\underline{-}$ & $\begin{array}{l}\bar{t} \\
+\end{array}$ \\
\hline Central nervous system & + & - & + & + & + \\
\hline
\end{tabular}

*Not described

TABLE 2 Skeletal abnormalities in trisomy 9

\begin{tabular}{|c|c|c|c|c|}
\hline Cases reported & Absent bones & Hypoplastic bones & Dislocated joints & Other \\
\hline Case 1 & None* & $\begin{array}{l}\text { Pelvis, } \\
\text { proximal tibial } \\
\text { epiphyses }\end{array}$ & $\begin{array}{l}\text { Hips, } \\
\text { elbows, } \\
\text { 1st toes }\end{array}$ & $\begin{array}{l}\text { Camptodactyly, } \\
\text { flexion contractures of knees, } \\
\text { equinovalgus }\end{array}$ \\
\hline Case 2 & $X$-rays not done & & Hips & $\begin{array}{l}\text { Camptodactyly, } \\
\text { overlapping fingers, } \\
\text { hyperextensible knees, } \\
\text { equinovalgus }\end{array}$ \\
\hline $\begin{array}{l}\text { Feingold and } \\
\text { Atkins }^{3} \text {; Kurnick } \text { et } \text { al }^{4}\end{array}$ & $\begin{array}{l}\text { Phalanges, fibula, tarsal, } \\
\text { calcaneal metatarsals, toes }\end{array}$ & Tibia & Elbows & Camptodactyly \\
\hline Seabright et al ${ }^{5}$ & $\dagger$ & $\dagger$ & Hips & $\begin{array}{l}\text { Fixed extension of knees, } \\
\text { malformed hands }\end{array}$ \\
\hline Mace et al6 & $\begin{array}{l}\text { Phalanges, } \\
\text { fingers and toes }\end{array}$ & Short metacarpals & Hips & $\begin{array}{l}\text { Overlapping fingers } \\
\text { calcaneovalgus deformities, } \\
\text { abnormal ossification } \\
\text { of the pelvis }\end{array}$ \\
\hline
\end{tabular}

*Only the bones of extremities, skull, and pelvis were examined.

$\dagger$ Not described.

The rarity of trisomy 9 in liveborn infants is indicated by the paucity of reported cases and by the lack of any such infant among the 56952 newborns studied cytogenetically in six surveys. ${ }^{13}$ However, trisomy 9 is not a rare finding in spontaneous abortions. In a number of studies, it has been noted that approximately $25 \%$ have an autosomal trisomy and of these abortuses $2 \cdot 2$ to $2 \cdot 7 \%$ are trisomic for chromosome 9.14 15 From these data and a spontaneous abortion rate of at least $15 \%$ in the general population it can be estimated that trisomy 9 occurs in about 1 per 1000 recognised conceptions. Almost none of these trisomy 9 conceptuses will survive to be liveborn. For comparison, based on these same surveys, an estimated 5 per 1000 conceptuses have trisomy 21 with approximately $20 \%$ surviving to be liveborn at or near term.

Little is known regarding the underlying aetiology of trisomy 9. Based on a small number of cases there is little evidence of advanced parental age. For all cases, both with and without mosaicism and whether aborted or liveborn, the mean maternal age is 28.4 years (19 cases) and the mean paternal age is 29.5 years (13 cases). For the only five liveborn infants with trisomy 9 these ages are 22.0 and 22.2 years and for the abortuses 28.4 ( 9 cases) and $29 \cdot 5$ years ( 3 cases), respectively. In six cases with trisomy 9 mosaicism the mean maternal age was 28.3 years and 
the mean paternal age 33.2 years. Although the parental ages in the mosaic cases are higher than the former, the difference is of doubtful importance because of the small number of cases and the lack of knowledge of parental ages in the general populations from which they came.

In most instances of trisomy 9 the origin of the extra chromosome has not been determined. In each of our two cases the lack of distinctive heteromorphic regions of the chromosome 9 in the patients and the parents made such a determination impossible. However, in the case reported by Seabright et al, ${ }^{5}$ $\mathrm{C}$ band variants of the chromosomes 9 indicated that two of these chromosomes in the patient were likely to have been of maternal origin.

A high frequency of spermatozoa with two chromosomes 9 has been reported. Pearson et al ${ }^{16}$ studied the spermatozoa from three males (ages not indicated), using the Giemsa 11 technique which distinctly stains the $\mathrm{C}$ band region of chromosome 9 in both metaphase and interphase cells. Of the spermatozoa in the three samples, 2 to $4 \%$ (average $2 \cdot 8$ ) contained two chromosomes 9 . Whether this observation is relevant to the possible origin of the extra chromosome in trisomy 9 abortuses and liveborn infants is questionable. In other trisomies for which this determination can be made, a considerable majority of cases had an extra chromosome derived from the mother. ${ }^{17}$ This is true not only for those cases with trisomies of chromosomes 13,14, 15, 21, and 22, which show an increased parental age, but also for trisomy 16 , in which a parental age effect is not apparent.

The diagnostic value of performing chromosome studies in instances of perinatal death is illustrated by these two cases. Chromosome abnormalities are found in 4 to $6 \%$ of perinatal deaths (fresh stillbirths and neonatal deaths). ${ }^{18}$ In such deaths the proportion of those with a chromosome abnormality is even higher $(13 \%)$ if multiple congenital malformations are present. In this latter group the type of chromosome abnormality usually reported has been autosomal trisomy, most commonly of chromosomes 13 , 18,21 , or, infrequently, one belonging to the $\mathrm{C}$ group (not identified by banding studies). The discovery of such an abnormality establishes the diagnosis and provides the basis for counselling parents regarding the risk of recurrence in subsequent pregnancies.

The risk of a chromosome abnormality occurring in another child of a mother who has had a conceptus with trisomy 9, either liveborn or aborted, is unknown because of the very small number of reported cases. Based on experience with trisomies in general, it appears that a mother who has had one trisomic conceptus is at increased risk of having another conceptus with trisomy (with a good chance of involvement of a different chromosome). ${ }^{19}$ The magnitude of this risk has not been determined and whether this increased risk applies only to cases with trisomies that are clearly age-dependent (chromosomes $13,14,15,18,21$, and 22) or to all trisomies is presently unknown. Until this is clarified Jacobs ${ }^{19}$ has suggested "to consider all women who are known to have had a trisomic conceptus as being at an increased risk and to offer them amniocentesis for future pregnancies". The mother of case 1 of this report did have amniocentesis for prenatal diagnosis during her next pregnancy. No chromosomal abnormality was found and she subsequently gave birth to a normal appearing male.

We wish to thank Drs J Branch, M Ludwig, M Bibro, and K W Barwick of the Department of Pathology, Yale University School of Medicine, for their assistance. The technical assistance of V F Powers, D N Swiatek, and C Grantham is gratefully acknowledged. This study was supported in part by a US Public Health Service research grant, HD-11624.

\section{References}

1 Boué J, Boué A, Deluchat C, Perraudin N, Yvert F. Identification of $\mathrm{C}$ trisomies in human abortuses. $\mathrm{J}$ Med Genet 1975;12:265-8.

2 Lauritsen JG. Aetiology of spontaneous abortions-a cytogenetic and epidemiological study of 288 abortuses and their parents. Acta Obstet Gynaecol Scand [Suppl] 1976;52:1-29.

${ }^{3}$ Feingold M, Atkins L. A case of trisomy 9. J Med Genet 1973;10:184-7.

4 Kurnick J, Atkins L, Feingold M, Hills J, Dvorak A. Trisomy 9: predominance of cardiovascular, liver, brain, and skeletal anomalies in the first diagnosed case. Hum Pathol 1973;5:223-32.

5 Seabright M, Gregson N, Mould S. Trisomy 9 associated with enlarged $9 \mathrm{qh}$ segment in a liveborn. Hum Genet 1976 ; 34:323-5.

6 Mace SE, MacIntyre MN, Turk KB, Johnson WE. The trisomy 9 syndrome. Multiple congenital anomalies and unusual pathological findings. J Pediatr 1978;92:446-8.

7 Centerwall WR, Peatty-Desana J. The trisomy 9p syndrome. Pediatrics $1975 ; 56: 748-55$.

8 Turleau C, de Grouchy JDE, Chavin-Colin F, et al. Partial trisomy 9q. A new syndrome. Humangenetik 1975; 29:233-41.

9 Faed M, Robertson J, Brown S, Smail PJ, Muckart RD. Pure partial trisomy for the long arm of chromosome 9. J Med Genet 1976;13:239-42.

10 Sutherland GR, Carter RF, Morris LL. Partial and complete trisomy 9 : delineation of a trisomy 9 syndrome. Hum Genet 1976;32:133-40.

${ }^{11}$ Lewandowski R, Yunis J. Trisomy 9 mosaicism. Clin Genet 1977;11:306-10.

12 Tropp M, Currie M. Mosaic trisomy 9: two additional cases. Hum Genet 1977; 38:131-5. 
13 Hook EB, Hamerton JL. The frequency of chromosome abnormalities detected in consecutive newborn studies. In: Hook EB, Porter IH, eds. Population cytogenetics in humans. New York: Academic Press, 1977:63-79.

14 Jacobs PA. Epidemiology of chromosome abnormalities in man. Am J Epidemiol 1977;105:180-91.

15 Carr DH, Gedeon M. Population cytogenetics of human abortuses. In: Hook EB, Porter IH, eds. Population cytogenetics in humans. New York: Academic Press, 1977: $1-9$.

16 Pearson PL, Geraedts JPM, Pawlowitski IH. Chromosomal error in relation to reproductive failure. Paris: INSERM, $1973 ; 219-29$.

17 Jacobs PA, Hassold TJ. The origin of chromosome abnormalities in spontaneous abortions. In: Hook EB,
Porter IH, eds. Human embryonic and fetal death. New York: Academic Press, 1980:289-98.

18 Machin GA, Crolla JA. Chromosome constitution of $500 \stackrel{\overline{\mathcal{S}}}{-}$ infants dying during the perinatal period. HumangenetikO 1974;23:183-98.

19 Jacobs PA. Recurrence risks for chromosome abnormalities. In: Epstein CJ, et al, eds. Risk, communication and decision making in genetic counselling. New York:® Alan R Liss, 1979:71-80.

Requests for reprints to Dr W R Breg, Department $\overrightarrow{0}$ of Human Genetics, Yale University School of $\overrightarrow{\vec{\omega}}$ Medicine, 333 Cedar Street, New Haven, Connecticut 06510 , USA. 